\title{
Social Transformation in the Northern Coastal Cities of Java: a Comparative Study in Cirebon and Gresik ${ }^{1}$
}

\author{
Riwanto Tirtosudarmo \\ Research Center for Society and Culture \\ Indonesian Institute of Sciences
}

\section{Introduction}

Java, the most densely populated island of insular Southeast Asiathe Indonesian archipelago - is a well known historical site for its embracing of world civilisations: Indic, Sinic and Western. The important commodities produced in this region, cloves and pepper among many other spices, attracted the contemporary global powers of the seventeenth century (the Portuguese, Spanish, Dutch and the British) to conquer and eventually partition the region as their far eastern colonies. From this global commercial competition, cities in Java, particularly its northern coastal cities, developed into significant trading ports as well as military posts. The failures of local rulers in Java to defend their territories from the European powers resulted in the long period of colonisation that left strong historical legacies that continue until today. The contemporary social transformations in the cities along the northern coast of Java is, however, still generally under researched and since independence there have been many urban and spatial changes in the area, which have not been always beneficial to the people living there. Problems, such as poverty, crime and environmental degradation seem to be increasing side by side with the process of urbanisation and infrastructure development.

1 This is an extraction of a research report prepared by Riwanto Tirtosudarmo (team leader), Thung Julan, Soewarsono, Abdul Rachman Patji, Imelda, Aulia Hadi and Alie Humaedi; all are researchers at the Research Center for Society and Culture, Indonesian Institute of Sciences. 
We observed in Cirebon, for instance, the striking decline of a formerly well-known harbour city. A new toll road at the city's outskirts has brought profound changes to the city's environs and its people. The people have to reconstruct the future of their city, either as a 'religious' city as it was known in the past, or as a commercial city able to meet the needs of modern capitalist development. The growth of Gresik as an industrial support city for Surabaya has caused it (Surabaya) to lose its traditional reputation as a religious city. From the literature on urban studies, such problems originate from the fact that even though, historically, cities along the north coast of Java developed as a result of the growth of inter-city networks, many recent developments have tended to destroy the previous social networks. There is almost no space for the people living in the cities to express their interpretation and expectations of their city. Looking at the city from several aspects, this study is an attempt to explore how the people of Cirebon and Gresik articulate their views on their cities and how they interact with the city governments and the economy in order to make the city a better social living space.

\section{Scope, Approach and Focus of the Study}

The scope of the study is limited to two dimensions of the relation between a city and its people, that is, a physical dimension (for example, city infrastructures) and a social dimension (for example, symbolic meaning of the city). The study adopted a qualitative approach that focuses on the perception of various communities in relation to the physical arrangement of the cities, particularly the harbour and the railways as the main gate(s) for interactions with the outside world. This is the first year, we hope, of a research study over many years on social transformations in Java's northern coastal cities. In the first year, Cirebon and Gresik have been selected for three reasons: first, they are, historically, important trading ports; second, historically, they have been centres of Islamic teaching in Java; and, third, they are places where the inhabitants are culturally heterogeneous, especially with the dominant role of the Chinese and the Hadramis. As well as from the literature 
reviews and other secondary sources, a series of workshops was held before a short fieldwork study was conducted in Cirebon and Gresik in July 2009. Unstructured interviews with the key resource persons were conducted by the team members. In addition, focus group discussions were also conducted in Cirebon and in Gresik, among other reasons to reconcile the often divergent views among the key informants.

Urban studies in developing countries generally concentrate on the development of the mega-cities; such as Jakarta, Surabaya, Kuala Lumpur, Penang, Bangkok, Chiang Mai, Manila, Cebu and Ho Chi Min City. Medium-size and small cities are no less important to be observed because these cities are where the flow of goods, labour and capital often originate and are transferred. Michael Leaf (2008) describes these medium and small cities as 'the transition zone, or interaction zone, where urban and rural activities are juxtaposed, and landscape features are subject to rapid modifications, induced by anthropogenic activity'. ${ }^{2}$ As transition zones, medium and small cities are often geographically close to the big cities - satellite cities you could say — and constitute the urban space in which urban and rural forms of human activities co-exist, which in turn bring the social and political implications to the spatial formation and social transformation of the city's inhabitants.

The cities along the north coast of Java were chosen for this study because they exemplify social transformation in urban areas of contemporary Indonesia. A knowledge and understanding of how the social and cultural patterns of such cities are changing has implications for planners and policy makers. The area has a long history as the centre of trading and civilisation and constituting the hybrid and plural societies in Indonesia. The study also hoped to contribute to the still limited number of social research projects on medium-size cities as transitional zones, as argued by Michael Leaf above. Currently, the spatial development of urban areas along the north coast of Java has been strongly dominated by the three megacities, namely, Jakarta in the west, Semarang in the middle,

2 Michael Leaf, 2008, 'New Urban Frontiers: Periurbanization and (re) territorialization in Southeast Asia', paper presented at the Regional Conference, Trends in urbanization and periurbanization in South-East Asia, CEFURDS/IRD, Ho Chi Minh City, 9 to 11 December 2008. 
and Surabaya in the east. The medium and small cities spreading along the north coast are in between these three megacities: Anyer, Serang, Tanggerang, Bekasi, Subang, Karawang, Cikampek, Indramayu, Cirebon and Losari (West Java); Brebes, Tegal, Pekalongan, Batang, Weleri, Kendal, Kudus, Jepara, Pati, Juwana, Rembang and Lasem (Central Java); Tuban, Gresik, Probolinggo, Pasuruan, Panarukan and Banyuwangi (East Java).

For this study, social transformation is defined as 'rapid social change that is assumed to be the main character of urban areas'. Generally, at least three indicators are used for the designation of an urban area: (1) the significant role of trading, industries and services in the economy, (2) the social and cultural diversity of its population that reflects a high rate of in-migration, and (3) a large proportion of population engaged in the informal sectors of the economy. This study adopted a socio-cultural perspective in which social transformation is perceived as the outcome of interactions between citizens, state and market. Urban areas and cities are not only understood as a physical space but also as social space with its embedded symbolic meanings. Interactions and competition that occurs between the citizens, the state and the market are assumed not only to contribute to the development of physical space and the city's infrastructures (ports, transport systems, settlement pattern) but also in the social construction of a city's identity and its symbolic meanings that represent historical imprints of its constituent societies. The social transformation of urban areas is a long and complex process in which continuity and change occurs along the course of their history.

\section{Structure of the Report}

The report begins with an historical description of the 'social space' of the two cities, Cirebon and Gresik, as perceived from political and economic perspectives, demonstrating how the harbours in those two cities were gradually detached from the social space where they are located. The second and third parts talk about 'outside forces' that control city development, particularly the harbour and railways, making it 'a 
city without people'; the fourth part discusses the symbolic meaning of Cirebon and Gresik as 'religious' cities; the fifth part exposes the grass root people's 'social network' that creates a cross-cultural strategy of adaptation to the difficulties of urban life. The two final chapters talk about urban life based on the experiences of the Arabs and the Chinese as two long-established migrant communities. Although economic development has not always improved the welfare of most of the people, the study shows the continuation of rapid social transformation and the hybrid nature of urban areas in the north coast cities of Java. As the focus of this research is multidimensional, complex and on related social and cultural aspects, it was agreed, and found more practical, that each team member concentrate and focus on one aspect of the social transformations in Cirebon and Gresik. Those aspects are: (1) social history, (2) symbolic meaning, (3) urbanisation and marginalisation, (4) railways, (5) Hadrami community, (6) Chinese community, and (7) cultural encounters. The following are extracts of the main findings of the exploration of each aspect.

\section{Social history}

In the first chapter, Soewarsono, based on various historical sources, argues that every political regime, from pre-colonial to post-colonial; has influenced the spatial design and infrastructure of the cities. The different political regimes affected the political and economic functions of the city's infrastructures as well as the pattern of population residence. The changing features of city governments that follow the changing of a political regime, often repeating the previous pattern or in other cases representing the new inventions that inspired by the previous patterns. Whether militaristic or administrative, centralisation and decentralisation of power have always had a significant effect on the changing landscape and the infrastructures in order to support the economic and political interests of the dominant political regime. The international demand for agricultural commodities that are produced mostly in the hinterland of Java has had strong influences on the development of transport systems, including the construction of harbours, roads and the railways along the 
coast as well as to the interior of Java. Technological change and the development of industries have also created new economic processes that, in turn, influence the spatial design and settlement patterns of the cities.

\section{Symbolic meanings}

In the second chapter, Aulia Hadi traces the social and cultural processes in the construction of the cultural identities constructed by each city's inhabitants. Cirebon and Gresik are both known as centres for the teaching of Islam in Java; so undoubtedly, Islamic nuances are strongly felt in the contestation for constructing identities and symbolic meanings of the city. By identifying different groups in the societies, according to their role in the discourse of symbolic meaning of the city, it is possible to understand then how the contest is manifested and what cultural tendencies are revealed. The interesting finding is related to the fact that the label given to Cirebon and Gresik is Kota Wali or 'Saint City', originating from their histories, which is apparently changing, because now the emphasis is more on the instrumentalisation of religion to strengthen the Islamic characteristic of the cities. The label that is given to the city depends on the desires of the city's elite, rather than the common inhabitants, in constructing their city's symbolic meaning. The different elite groups in the society tend to dominate and hegemonise the society through their constructed discourses. The increasing pressures coming from the market economy outside the society, however, began to be felt through the flows of capital, goods and information. Understanding the new role of a market economy in the construction of a symbolic meaning of the city is therefore very important for future research.

\section{Urbanisation and marginalisation}

In the third chapter, Riwanto Tirtosudarmo found that urbanisation in Gresik and Cirebon are not following what has occurred in the West where improvement in economic welfare of the citizens is part of the 
urbanisation process. In Gresik it was found that rapid industrialisation has produced more destitute workers and in Cirebon, trade expansion only produced a burgeoning number of people engaged in the informal economic sector, which is perceived to be the source of the city's public disorder. The increasing gap between the upper and lower economic classes could potentially be the source of social tensions and conflict in Cirebon and Gresik. In conflicts that are caused by economic disparities between classes, the governments and civil societies of both cities apparently have very little role in finding resolutions to the conflict and in defending the cities' marginalised inhabitants. The proposition that is put forward in this study, that urban space is determined more by city government, apparently is not supported by the realities as observed in Gresik and Cirebon. The urban space, physically or symbolically, is transformed not by design by city government or citizens, but is more influenced by external intervention, particularly by the central government and trans-national capital. Cirebon and Gresik, following the idea of Lefebvre's on the production of space, show that citizens have little role in contributing to the construction of the urban space compared with other forces, such as capital and the market. From the perspective of urban studies, Cirebon and Gresik followed the general pattern where the sub-urbanisation and rural-urban migration is the dominant paradigm. The burgeoning numbers of urban proletariat, mostly engaged as low-wage industrial workers or as part of the informal economy, strongly characterise the development of both cities.

\section{Railways and city economics}

In chapter four, Imelda analyses the city's economy through the lens of railway infrastructural development in Cirebon and Gresik. From her analysis, it has become clear that the development of business, trade and industry can not be isolated from the development of railway transport. In Cirebon, in the past, trading was very lively and now this city is the location for trading company head offices that represent the foreign states and that coordinate the import and export of goods and commodities. Railway transport plays a vital role in distributing agricultural products 
from the hinterland to other places. In Gresik, railways also contributed significantly to the transport of industrial products from factories to various destinations. The current condition of the railway system, unfortunately, has deteriorated drastically. Observations have shown that the railway system in Cirebon now functions primarily for passengers rather than goods. In Gresik, the railways are almost totally dead. The current state of railway development observed in Gresik and Cirebon should be the concern of all parties; if nothing is done then railways will not be able to survive.

\section{The Hadramis and the spread of Islam}

In part five of this research report, Abdurachman Patji focused his investigation on Hadrami society. Although, when they first settled, the Hadramis played limited roles because they were immigrants but they slowly gained a special niche in the urban social space of Cirebon and Gresik. The Hadramis were especially skilled traders but they also developed a special position in education, particularly in spreading Islamic teaching. Currently, in Cirebon and Gresik, Hadramis are more recognised for their development of Islamic education institutions than as traders, because the Hadrami leaders are consistently able to transfer their knowledge and interpretation of Islam as needed by the wider society. There are, however, slight differences in the way the Hadramis organised the Islamic education in Cirebon and Gresik. In Cirebon, the Hadrami education institutions are divided into the Sayyid and nonSayyid group, but in Gresik there is no such division. The two groups, Sayyid and non-Sayyid, in Cirebon were also reflected in two different education institutions; Darul Hikam belongs to the Sayyid, and AlIrsyad belongs to the non-Sayyid. Although the two streams of Islamic teaching, represented by Darul Hikam and Al-Irsyad, are also present in Gresik, they did not give rise to separate education institutions. The other aspects of Hadrami society, such as their settlement pattern, social and economic lives, are similar in Gresik and Cirebon. Beyond their internal differences and similarities, the role and place of Hadrami societies in Cirebon and Gresik area important in the urban social 
transformation, yet as far as the literature is concerned, little has been written of their formal history.

\section{The declining role of the Chinese}

Thung Julan reveals her findings on the Chinese communities in part six of the report. There is much evidence that the Chinese had a significant role in transforming the city's social space in the past, in Cirebon and in Gresik. Apart from the fact that they were historically known in Java as urban dwellers, the Chinese also have a significant place in the local economy. The Chinese are also recognised as playing a role in spreading Islam in the north coast cities of Java; for example, in Cirebon, one wife of Sunan Gunung Jati, Nyi Ong Tien, was of Chinese descent. Also there is a strong belief that Admiral Cheng Ho, a Muslim, played a very influential role in promoting the spread of Islam in Gresik. The role of the Chinese communities, however, began to decline after Indonesian independence. The influential role of the Chinese in the economy, especially their control of big companies, has steadily deteriorated and this in turn reduced the social space that the Chinese communities previously enjoyed. In Gresik, the role of the Chinese is deteriorating rapidly and currently there are no Chinese organisations to be found except for those to do with funeral arrangements. In Cirebon, although the Chinese role is also declining, there seem to be indications of regeneration; some Chinese organisations still exist and recently a number of Chinese began to be involved in local politics. In general though, the role of the Chinese in Cirebon and Gresik is becoming less significant.

\section{Encounters with local cultures}

In part seven, Alie Humaedi explores the social relations between different local cultural identity groups. Apart from the fact that intercultural relations have generally produced new hybrid cultures, yet, as he observed in Gresik and Cirebon, they also produced a redrawing of cultural boundaries whose limits are often unrecognised. The 
influence of mainstream or dominant cultural practices, in vernacular languages and the rituals of social life, cannot be underestimated; particularly Sundanese customs and traditions in the case of Cirebon and the Javanese in the case of Gresik. The minority groups, formed usually from immigrants settling in an area, have had to merge their cultural identities with the larger dominant cultures. These intercultural relations between dominant and minority groups eventually affected the social transformation in several locations, which in turn influenced the pattern of social space in Cirebon and Gresik.

\section{Conclusion and Further Research}

Because it is the longest urban corridor in Indonesia, perhaps in Southeast Asia, the cities along the northern coast of Java should be studied seriously; rapid social change is undoubtedly shaping and reshaping the societies in this region. The rapid development of urban infrastructures, strongly related to the concentration of economic activities, has affected the pattern of settlements as well as the social and cultural dynamics of the population. Various aspects of the societies in Cirebon and Gresik, as the study has reported, clearly indicate the complex processes of social change that, economically and politically, do not always benefit citizens. The interaction of society, state and markets, exposes the relatively weak position of the citizens vis-a-vis the state and the market. The market is becoming more influential in determining the construction of the physical dimension of the cities as well as the symbolic meanings of the city. In general, the study concludes that a better understanding of the social and cultural dynamics in the cities is vital, especially for city governments in anticipating the negative effects of future development. Given the centrality of the location, further research on the social transformation of cities along the northern coast of Java is important because these urban corridors have significant social and economic influences on the future of Java and Indonesia as a whole. 